\title{
Low Cost Tertiary Education: The Price to Pay for Knowledge-Business Hub-The Mauritius Transitional Education Case Study
}

\author{
Rajendra Parsad GUNPUTH \\ University of Mauritius, Mauritius \\ rpgunput@uom.ac.mu
}

\begin{abstract}
Most United Kingdom (UK) universities are franchising fast with foreign universities affording low cost tertiary education. Most students and graduates in Mauritius have their degree and other awards from local, Indian or British universities. However, in the recent couple of years UK universities are franchising more and more with local institutions (University of Mauritius and University of Technology Mauritius) with large campuses on the small island of the Republic of Mauritius. Of both French (1715-1810) and British colonisation (1810-1968) until its independence in 1968 the young Republic of Mauritius (12 March 1992) is one of the leading countries in Africa where secondary education is free with a relative weaker fee to enter in tertiary institutions like the University of Mauritius. In a contextualised approach the study that shall follow explain the actual situation transition education in Mauritius where local students are less and less reluctant to go to the UK to have a degree. In return UK universities instead are mushrooming around the island attracting local students who cannot afford to pay high cost tertiary education in countries like the USA, France or the UK. Actually, UK universities are recruiting local academics to lecture on their programmes in Mauritius for local students who despite their high profile cannot afford to pay the fees in the USA or UK. UK universities are also sending their staff to lecture in Mauritius and local students have the same award they would receive in the UK. Indeed, the research reflects to what extent students are willing to remain in Mauritius to avoid obstacles and harassment they would probably face in the UK or the USA in terms of visas, accommodation, job facilities just to name a few. But there is still a cost to pay.
\end{abstract}

Key words: Transitional education, franchising, globalisation, competitiveness, Mauritius

\section{Introduction}

In a contextualised approach, this article deals with management of first class tertiary education at a relatively low cost and it can be achieved by allowing overseas educational and training institutions to settle in the country but there is a cost to pay. Actually, Mauritius is experiencing a new sort of higher education: overseas institutions (from UK principally)are franchising their programmes at low cost without, however, having in return any written exam or efficient quality control in their post graduate programmes but in return local students have a degree and some training. Prevention is better than cure they say but because of its good reputation; good political stability, free and fair elections, respect of human rights; on the African continent and in the Indian Ocean it is not denied that Mauritius is a centre of excellence with its free education for one and all at primary and secondary levels with a symbolic fee at tertiary level. It explains once more the policy of the Mauritian government to give all students access to education, and second Mauritius remains a Welfare State with free health services, transport facilities and good quality of life and social security.

With time, more and more foreign institutions are tempted to settle in the country and actually they are mushrooming on the island attracting more and more scholars, foreign experts, local students, and even overseas students. Overseas institutions take the lion's shares when they are affiliated to local private institutions (infra) but their local partners are also making large profit but there is another cost to pay in terms of quality and quality control. Whatsoever, the problem of the local government is elsewhere. Its main objective is that the country shall be a centre, at any cost, for a 'knowledge hub' on the African continent provided in the long run there would be at least one degree holder in each and every family. The other side of the picture is that there are issues related to unemployment and degree holders who are remunerated for a job for which they deserve more. Furthermore, most tertiary institutions are issuing the same degree but the 
level and standard are different from one institution to another and from one degree holder to another. The University of Mauritius, with its population of 14,000 students, cannot of course guarantee a seat to all school leavers. And a good majority of them had to fly abroad (India, England, France, Australia, Pakistan) not only because seats are unavailable in Mauritius but there are fields which are not within the knowledge of local academics and/or which local institutions are unable to offer (medicine, dentistry, astrophysics) though, with time, most fields are now available in the country. Nevertheless, fees are getting more expensive abroad and most British universities are franchising their courses and programmes in Mauritius but, again and once more, at what cost? Most programmes which are delivered at undergraduate or postgraduate levels in England are also delivered in Mauritius but there are no written exams. In contrast, there is a large amount of assignments and a dissertation which is compulsory. It is not denied that there is first class education in Mauritius, which is a different issue, but the ultimate issue here is that candidates have no proper professional standard and the level is on the slope.

The Mauritian government is in favour of a 'knowledge hub' which can give access to foreign students as well and though there are public universities, two polytechnics and a range of other tertiary education institutions as well as a number of private, regional and international overseas institutions there is yet no proper quality control and assessment but over and above all local institutions are unable to satisfy the demand. The solution, which is not new, exists in Singapore and Malaysia, was to attract more and more foreign universities of high reputation to settle in Mauritius. Unemployment is still low among graduates. However, according to a report of the $\mathrm{OCDE}^{1}$ on education:

"For young people, a good education provides valuable insurance against a lack of work experience, even during a crisis: across OECD countries, an average of 18.1\% of 25-34 year-olds without secondary education was unemployed in 2011, compared with 8.8\% of 55-64 year-olds. Among 25-34 year-olds with a tertiary qualification, $6.8 \%$, on average, were unemployed, compared with $4.0 \%$ of $55-64$ year-olds with a similar level of education (Indicator A5)".

Most tertiary institutions need funds and they wish to increase their fees at a time where every student has very few opportunities to study locally or abroad. Is it possible to raise a first class tertiary education at a relatively low cost so that tertiary education is accessible to one and all without discrimination? The author relies on the Mauritian experience reflecting to what extent democratisation of tertiary education has been possible by allowing international and universally recognised universities to set up on the Mauritian land. The flood gate is eventually open but there are pros and cons of foreign international tertiary institutions pushing knowledge to a new sense of wonder and to awareness: true is it that there is democratisation of tertiary education leaving access to foreign and overseas institutions but at what cost?

This study will enable us to understand problematic and persistent issues such as quality control, assessment, quality assurance, moderation just to name a few and to think twice prior to authorise overseas institutions to settle in the country. After an introduction, this paper is built on nine different floors to include an overview problem statement (II), a literature review (III), the legal and institutional framework (IV), the pros and cons of international universities in Mauritius (V), Vocational and technical institutions and other training institutions (VI), a conclusion with some recommendations will end with this paper (VII) followed by some references, which have been discussed in this paper will close this paper on transitional education in Mauritius.

Problem statement: Why is there a cost to pay for knowledge in Mauritius? According to OCDE2:

"Data also show the popularity of studying abroad, particularly among students from Asia. In 2011, 4.3 million tertiary students were enrolled in programmes outside their country of citizenship. Australia, the United Kingdom, Switzerland, New Zealand and Austria have, in descending order, the highest

\footnotetext{
${ }^{1}$ OECD Multilingual Summaries Education at a Glance 2013. OECD Indicators
}

20ECD Multilingual Summaries Education at a Glance 2013. OECD Indicators 
percentages of international students among their tertiary enrolments. The number of foreign students enrolled in tertiary education in OECD countries was almost three times the number of citizens from an OECD country studying abroad (Indicator C4)".

Irrespective they are local or foreign tertiary institutions universities need funds to survive in a competitive world. Over and above, local institutions survive with funds from the government and up to $65 \%$. And this amount is in decline every year. Logically, they would have to be self-funded within the years to come. Either they increase fees or attract funds from foreign universities which are awaiting to have the green light to settle in Mauritius. However, despite transitional education brings hope for students who cannot fund their studies in the UK, France or the USA they also bring despair because their fees are on the rise as well. In contrast, countries (Malaysia, Mauritius) which imported foreign institutions are now recruiting foreign academics and foreign students as well. The national policy is one graduate in each and every home irrespective there is employment or not (Chart 1 and Chart 2). The pass rate of School Certificate and higher School Certificate (Figure 1) is also high which means that they are motivated to join a tertiary institutions to pursue their studies either in Mauritius or abroad since there are various financial facilities (loan with low interest-5\%, scholarships for the best students and low fees for students who come from a poor background) available to local students.

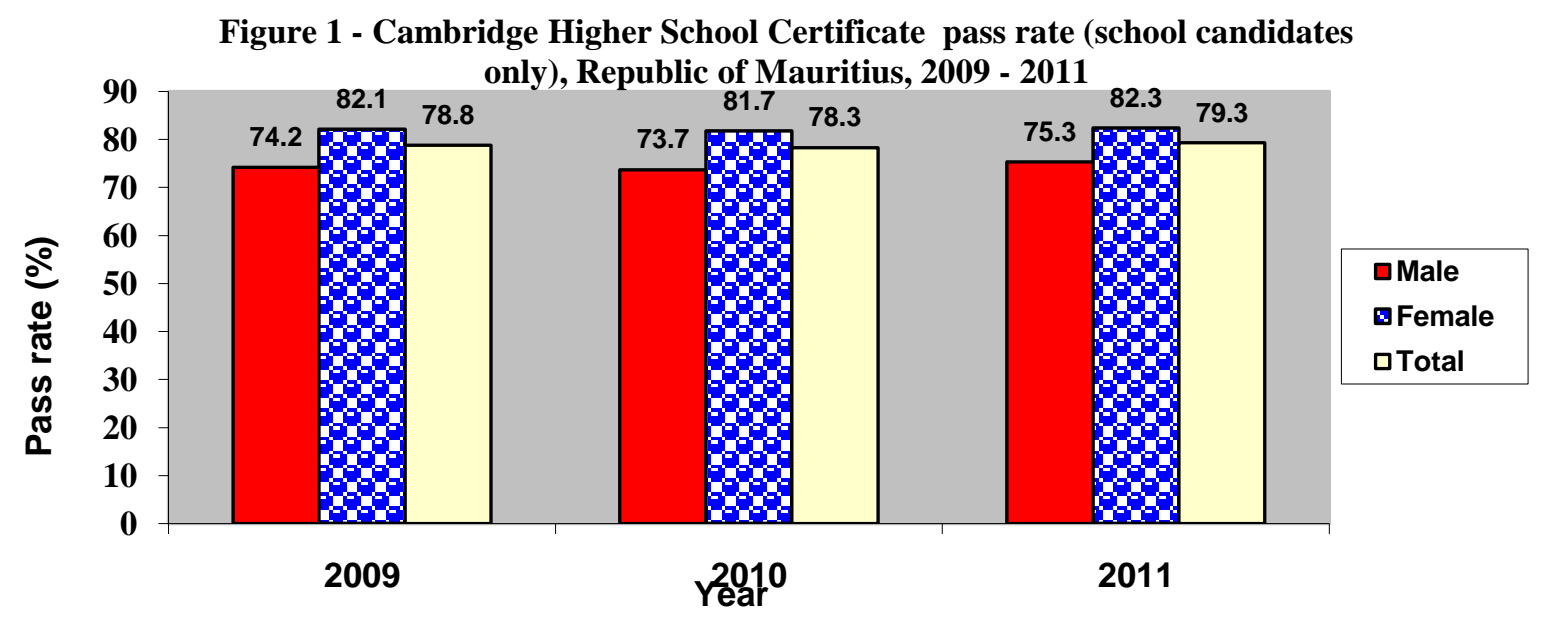

(Source: Central Statistics Office-CSO)

Foreign institutions from UK most especially wish to attract Mauritian students on their campuses in Mauritius. In the overall, there are more business money minded institutions and commercialisation than proper and high level education per se destroying the reputations of foreign and local institutions as well. Indeed, it has also been found in Mauritius that students who fail to secure a seat in the best local universities find easily a seat in foreign institutions even if they have poor results. Most students in Mauritius if not all obtain their examination results from the prestigious University of Cambridge satisfying the entry requirements of most foreign universities which have settled in Mauritius. According to Central Statistics Office Mauritius:

"As at December 2011, the total number of students (part-time and full-time) enrolled on tertiary-level programmes (including Distance Education) reached 45,969 compared to 44,334 in December 2010, representing an increase of $3.7 \%$.The majority of students (78\%) were enrolled in tertiary education locally in both public-funded institutions (49\%) and private institutions (29\%). The remaining $22 \%$ of the students were enrolled in tertiary education overseas (Table 8.1b). The Gross Enrolment Ratio (tertiary education enrolment as a percentage of the population aged 20 to 24 years), which was $45.1 \%$ in 2010 , decreased to $45.0 \%$ in $2011 "$. 


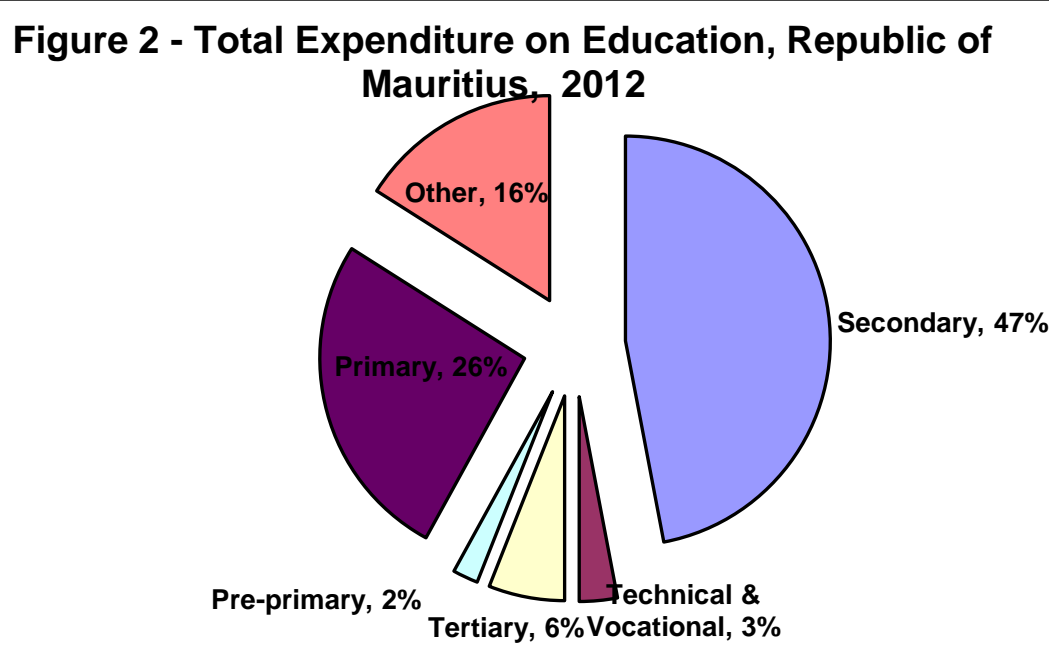

(Source: Central Statistics Office)

Since Mauritius is a Welfare State the national policy of the Mauritian government is to provide free education to one and all. In this respect, in the tertiary education, students like third-age citizens have free transport and low fees except for postgraduate programmes in public institutions. All citizens of Mauritius also enjoy free medical services in our hospitals and some medicine are also free as well. THerefore, tertiary institutions like the University of Mauritius receives subsidies from the government (Figure 2).

Chart 1 : Unemployed population by education attainment and sex, 2011
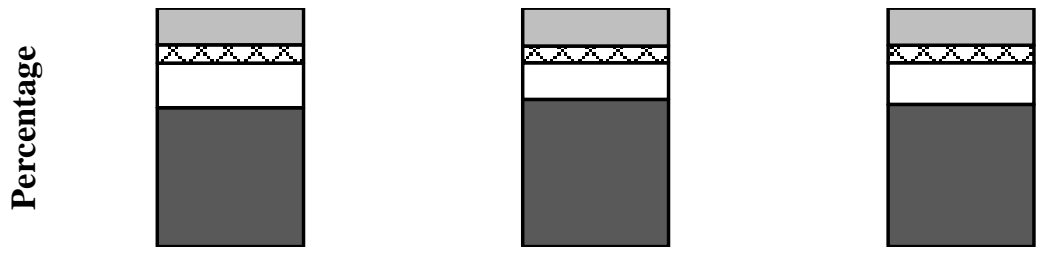

口Tertiarv $\quad$ aPassed HSC $\quad \square$ Passed SC $\quad \square$ Without SC

(Source: Central Statistics Office)

Chart 2 : Duration of unemployment by age group, 201

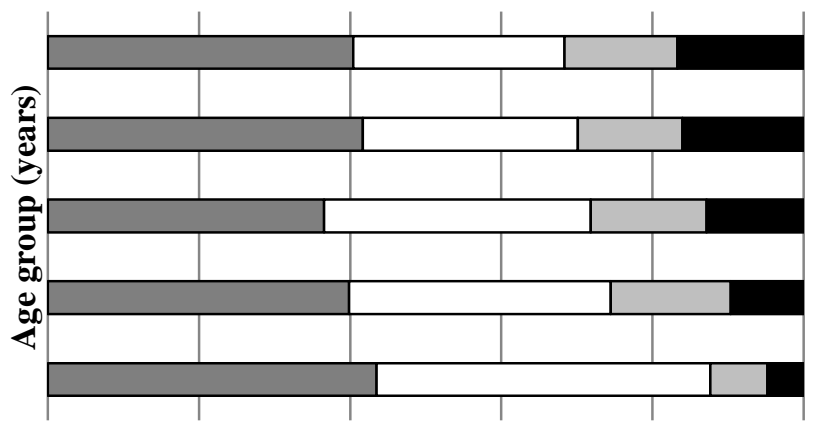

$\square \mathrm{Up}$ to $5 \mathrm{mths}$

口6-12 mths

13-24 mths

-25+ mths

(Source: Central Statistics Office) 


\section{Literature Review}

Economic, social and political developments in East Asian societies, like other parts of the globe, have been increasingly influenced by the growing impact of globalisation. Some authors found that higher education institutions are required to improve their administrative efficiency and accountability in response to the demands of different stakeholders, such as government, business, industry, and labour organisation, students and parents as well (Currie and Newson, 1998). Knowledge is portable and it lends itself easily to globalisation (Carnoy, 205). Globalisation, according to Dr Rejab Ismael, Director of International Business School, Universiti Teknologi Malaysia, has created awareness amongst universities and other institutions of higher learning that they must foster working relationships with their own overseas counterparts. This arises from the need to benchmark their performance with selected foreign universities in areas such as teaching pedagogy, course content and its market relevance, quality of the teaching faculty, learning facilities and work culture of the support staff.

Arshad-Ayaz (2008) defines globalisation as a phenomenon that subsumes into itself political, economical, social and cultural dynamics of the contemporary world whereas, in contrast, internationalisation is a philosophical ideology that is not economic in genesis but political and social in intent and is defined as the variety of policies and programmes that universities and governments implement to respond to globalisation. Joshee (2008:36) found that in education the neoliberal agenda stresses:

"global competitiveness, the reduction of the publicly financed costs of education, and of social reproduction in general, the necessity for greater market choice and accountability and the hierarchically conditioned, globally oriented state subjects that is individuals oriented to excel in every transforming situations of global competition, either as workers, managers or entrepreneurs".

For Apple 2000 seeking to create more quality education for their citizens but with only limited financial resources, modern universities have started to change their governance paradigm by adopting a doctrine of monetarism, which is characterised by freedom and markets replacing Keynesianism. It has also been found that relatively new universities gained a higher proportion of their independent revenue from overseas students than the older universities in 2001 (De Zilwa, 2005).The respected author went on to say that universities like Central Queensland, Curtin University of Technology and RMIT have revenues from overseas fees with 64\%, 52\% and 55\% respectively (De Zilwa, 2005). Therefore, privatisation of either the whole, or parts of, educational institutions, or indeed of sectors of education, (and other areas of social activity), is often now an instrument of economic and social (including education) policy, as is a more user-pays philosophy in education (World Bank 1995a; Mok, 1999). Internationalisation of higher education has been promoted dramatically since the 1980s, driven by the large increase in the number of students outside their home countries and as such accelerated student mobility in recent years has resulted in emergence of a global higher education market (Sugimoto, 2006). Relying on figures of the OECD (OECD, 2004a), the respected author (Sugimoto, 2006) found in his research paper that the number of international students across the world increased from 0.94 million in 1988 to 1.61 million in 1998 (a growth rate of approximately 70\% in the decade), and reached 1.9 million in 2002 and it is currently predicted that the number in emergence of a global higher education market has accelerated to reach 7.2 million by 2005 (Bohm, 2002).

According to Sugimoto (2006) Australia is currently the third-largest exporter of higher education services, after the US and the UK. Its education exports have been growing at an average rate of $11 \%$ per year since 1994 , to become its fourth largest source of export earnings ( $\mathrm{A} \$ .9$ billion) in 2004, behind coal, tourism and iron ore but, in consequence, the scale of its education services has expanded from $10 \%$ of total services in 1994 to $17 \%$ in 2004 (DFAT 2005, pp.48-50).Despite foreign institutions provide revenues there are some risks as well. In Malaysia, Monash University faced financial difficulties due to fewer students' numbers and growing costs. Consequently, it made a loss of $\$ 8.6$ million in 2003, and a total loss over three years of more than \$ 21 million (McBurnie, 2002, p. 4). British offshore programs enrolled around 140,000 students in 1996-1997, nearly as many international students as were studying in the UK at tertiary level the same year (OECD, 2002) whereas Australia, the second largest provider, had around 35,000 offshore students in 2001 (Ziguras, 2005). European countries provide for the best universities and this explain why a higher proportion of European and American students prefer to study in their own country. As an illustration, in 
2004 the top ten providers of overseas students in the Australian higher education sector were all Asian countries except the US, with $82.1 \%$ of international students $(228,555$ in total) from Asia (Nelson, 2005a, p. 23).

So, there are export earnings with transitional education. Furthermore, Xie 2001 found that the major pattern of conducting partnerships with foreign partners at an institutional level, two other types of administrative arrangements, operations, and revenue generation have emerged in Shanghai since the latter part of the 1990s. Transnational education is not the only the movement of students from one university to another or from one country to another as transnational education include borderless as well as cross-border education are terms that are being used to describe real or virtual movement of students, teachers, knowledge and educational programs from one country to another (Knight, 202). Just like many other countries, Huang (2006) found that one of the dramatic changes in mainland China's recent higher education has been to import foreign higher education services to Chinese campuses. Southeast Asia serves as a laboratory in this development with British, Australian and American universities at the forefront to compute the overseas educational dollars (Yang, 2006)

\section{The legal and institutional framework}

It is worth mentioning that school leavers may attend tertiary institutions, whether foreign or local, unless they have a minimum of standard and provided they can pay their annual fees. The policy of the government, since its independence on the $12^{\text {th }}$ March 1968, was to give access to free and fair education to one and all, though there were serious economic constraints whilst the country was relying on sugar for its survival and even went to subsidise a great part of the expenditure of the private confessional schools of the country. Though there have been serious economic miracles to economic debacles, the policy of the Mauritian government has been maintained. Education in Mauritius is still governed by an old Act of Parliament, the Education Act 1966. The Constitution of Mauritius also guarantees, inter alia, freedom of establishing schools and protection against discrimination. The major issue, prior to the settlement of foreign institutions in Mauritius, was the search of a legal and institutional framework both for local and foreign education coupled with strategic plans which were set up with a view to democratise education in the country. Several strategic plans (Table 1) were continually approved by the government to set the goals and milestones of the education sector to ensure access to learning opportunities to one and all.

\section{Table 1: Plan and strategies to achieve the MDG and EFA}

PLAN STRATEGIES

1 1971-1975 Four-Year Plan for Social Education must move from an academic emphasis to a more and Economic Development

2 1975-1980 Five-Year Plan technical and vocational orientation.

Unemployed are young and educated but they are not trained to participate in industrial development. Development of schools in rural areas.

3 1980-1982 Development Plan and The educational system shall be into conformity with 1984-1986 Development Plan employment opportunities and looking into qualitative and quantitative improvement at all levels within a cost effective system.

4 White Paper of 1984 and the Master Bridging the gap between school education and the job Plan in education in Nov. 1992 market

$5 \quad 2005-2010$

World class quality Education for all to enable young Mauritians to be employed in the new sectors of the economy, to have more fulfilling jobs and also to be competitive at the international level and National Curriculum Reform (2006)

$6 \quad 21^{\text {st }}$ century (beginning) Millennium Development Goals (MDG) for Education for All (EFA) 
Education is free in Mauritius, at the primary and secondary level with a very reasonable fee at tertiary level, opening the flood gate to one and all. As a result, the Tertiary Education Commission was set up in 1988 as a body corporate under the Tertiary Education Commission Act 1988 (Act 9/1988). Its major objectives were to promote secondary and tertiary education on the use of physical infrastructure, optimum use of manpower, organisation of teaching programmes and implementation of research. Since more and more overseas partners (Table 1) are willing to franchise their programmes with local institutions, there was a need to develop a strong legal and institutional framework and the TEC Act 2008 and the Licensing of recruiting agents for overseas educational and training institutions Act 2008 came into force so that all institutions and recruiting agents are managed properly to enhance quality control and management. The Licensing of recruiting agents for overseas educational and training institutions Act 2008 (Act No. 17 of 2006) provides for the regulations of persons or bodies recruiting students for admission to overseas educational and training institutions. Furthermore, the TEC Act 1988 is responsible for the establishment, registration and accreditation of overseas institutions and no person shall establish a post-secondary educational institution or a centre, or branch campus, of an overseas institution unless it has been approved by the Commission. Despite control by the TEC Act 1988 to different statutory tertiary institutions and other relevant bodies (Mahatma Gandhi Institute Act 1982, Mauritius College of the Air Act 1985, University of Mauritius Act 1971, University of Technology Act 2000, Maharishi Dayanand Institute Act 1984, Mauritius Institute of Education Act 1973) there are still a strong debate on the pros and cons of overseas institutions which are set up actually in Mauritius and which are out of control.

Overseas tertiary institutions in Mauritius: the pros and cons: Developing countries are an easy prey for overseas partner institutions. Many local students have a wish to have a degree from British universities, the USA or from Australia. When overseas institutions settle in foreign countries like partner institutions, the cost is relatively low had they pursued their studies at Cambridge, Oxford or Harvard. Overseas partner institutions were prompt to react when they discovered that Mauritius is a paradise for franchising their courses. Prior to their settlement, conditions such as political stability, economic miracles and good governance, inter alia, were encouraging and could guarantee an optimal climate for doing business education in Mauritius. Is it possible for any overseas partners to settle in a country without any flaws or at least to minimise them? Table 2 shows how foreign institutions are working in collaboration with their partner institutions to enhance the knowledge hub in Mauritius.

Overseas partners have invested in infrastructure and logistics. Even if overseas institutions may provide a degree to local students, there are still very serious discrepancies. None of them have been able to cater for the settlement of training centres and their local partners have to cater for it. So, with respect to management of foreign institutions in Mauritius, the first issue is what are the pros and cons of these tertiary institutions. There has been a lot of debates about pros and cons of foreign international universities. Though it is argued that it is hard sell for easy money, it is unanimously agreed that there are loopholes in the system: the standard is always questioned, there are no written or very few written exams, students have access to openbook examinations and external examiners only pay a flying visit and sometimes there may be no visits or moderation at all. Loopholes in the system do not indeed affect the students but something else. In fact, it is worth mentioning that it is not a deadly trap for students, for they will come out with a degree in return for the money they pay, but for both quality management and quality assurance.

Table 2: Knowledge hub

$\begin{array}{lll}\text { Foreign institutions in collaboration with } & \text { Programmes offered } & \text { Field }\end{array}$
local institutions

$\begin{array}{llll}\text { Middlesex University Mauritius Branch } & \begin{array}{l}\text { Licence Droit, Psychologie, l'Informatique, } \\ \text { Maîtrise de Gestion }\end{array} \\ 2 & \begin{array}{l}\text { Campus } \\ \text { Vatel Mauritius and Vatel International } \\ \text { Business School }\end{array} & \begin{array}{l}\text { Licence et Master en hôtellerie } \\ \text { internationale } \\ \text { Charles Telfair Institute and Curtin University }\end{array} & \text { Hachelor en commerce } \\ 3 & \begin{array}{l}\text { Rushmore Business School and European } \\ \text { Master of Business Administration (MBA) }\end{array} & \text {----- } \\ 5 & \text { TNA Analysis Maurice and l'Université de } & \text { MBA International Paris }\end{array}$


Paris Dauphine, IAE de Panthéon Sorbonne

6 Centre d'études supérieures (CES) and

Académie de la Réunion, IUT de Saint-Pierre, IAE de l'Université de Poitiers

$\begin{aligned} & \text { Licence, Master en } \begin{array}{r}\text { Informatique, ---- } \\ \text { entreprises, }\end{array} \\ & \text { Maninistration des } \\ & \text { Málectronique }\end{aligned}$ International, commerce

True is it that recruiting agents and their institutions are profit-making institutions but in return local students pay relatively lesser fees had they been in Australia or in British universities. Tertiary education is becoming more and more expensive while there is a strong demand for a knowledge hub. However, tertiary education involves a lot of commitments and funding is one of them. Furthermore, universities and institutions need funds for logistics, laboratory equipments, libraries, and softwares just to name a few. International financial crises, nature's wraths, cost of living, inflation, unemployment, poverty, political instability, poor management may also jeopardise education, whatever the level in a country. Consequently, less and less students are flying abroad because more and more international institutions of high calibre are set up in Mauritius actually but, though there are pros and cons about overseas institutions, in anyway are overseas franchises tarnishing UK universities' reputations? Mauritius is a commonwealth country like some African countries where students need their LLB (Hons) from British universities to practice locally, before municipal and domestic courts, and foreign British and Australian institutions are, in certain circumstances, more a blessing than a curse. The worst is to come. Local institutions like the University of Mauritius (UoM) is unable to secure a seat for all secondary school leavers and University of Technology Mauritius (UTM), the second public university on the land, has limited seats and programmes as well. If the selection process is rather harsh among local institutions the same is not true for overseas partner institutions. They recruit school leavers, where most applicants have relatively poor standard, without caring for performance and quality control provided they sell their programmes.

With the coming of the Law Practitioners Act 1984 (Act No. 55 of 1984, April 1, 1985) as amended by the Law Practitioners (Amendment) Act 2011, a law degree according to section 2 of the Act shall be one which is awarded by the University of Mauritius, a university in the United Kingdom, such university or other tertiary education institute in Mauritius, the United States, a Commonwealth country or a civil law State. Consequently, private and foreign institutions are mushrooming on the land where students may at least secure a seat but at which costs except to the paper they are printing their degree? And how to manage international universities and where is quality assurance if there is really one? The Licensing of recruiting agents for overseas educational and training institutions Act 2006 came into force coupled with the Tertiary Education Commission Act 1988 to monitor and oversee post-secondary education in Mauritius and to confirm whether the institution and the educational programme satisfy the minimum criteria or standards for it to operate or to be offered for a specified duration. However, any piece of legislation cannot substitute itself for management control, risk management and persistent issues like marketing and curriculum development.

There is a point where quality control managers have to draw the line: most postgraduate programmes had dissertations which cover between 40 percent and 100 percent of the total assessment but this is a very worrying trend. Above all, supervisors and assessors are overloaded with a good quota of dissertations of 15,000 words which they are unable to read and to submit on time, to detect plagiarism if any or to make fruitful comments after submission. If marks are on the high side, so be it, but the candidate has not been able to avoid the unavoidable but if there are opportunities to manage the unmanageable, sometimes there are few exits. The only exit is 'you pay you have a degree'. For the time being all undergraduate and postgraduate students are agreeable to this formula, because who will not be happy to have an easy degree, but for how long? For a short or long term? However, before they leave the auditorium and before they leave their caps where they have been freshly graduated there is one single question to remember: 'to what extent has I benefitted from these courses'? This is a big deal to remember.

Vocational and technical institutions and other training institutions: Overseas partner institutions are more theoretically oriented course, rarely provide training courses and if they could afford them, fees should climb exponentially indeed and consequently it would be useless to have overseas partners in a country where fees both local and abroad are practically the same. Practical's, whether in scientific fields or management, are virtually inexistent and local institutions have to complete the gap instead. Though the aim 
of the Mauritian government is to set up a knowledge hub in the country nonetheless there are still very few training institutions in Mauritius and strategic plans have been developed to push the knowledge hub forward (Table 1). There are more and more registered professional bodies in Mauritius (Table 3) and support comes from Britain, France and Australia.

\section{Table 3: Overseas partner institutions which are still operating in Mauritius}

\begin{tabular}{lll}
\hline & Overseas Institutions & Their local Partners in Mauritius \\
\hline 1 & Curtin University (Australia) & Charles Telfair Institute \\
2 & Vatel International Business School & Vatel Mauritius \\
3 & Institut de la Francophonie pour l'Entrepreneuriat & University of Mauritius \\
& (IFE)/France & \\
4 & Agence universitaire de la Francophonie (AUF)/France & University of Mauritius \\
5 & European Business School & Rushmore Business School \\
\hline
\end{tabular}

Actually, neither foreign international institutions nor local institutions have been able to set up proper training institutions in Mauritius though most public (Mauritius Police Force, University of Mauritius has its own 'training of trainers') and private institutions have their own training institutions but, once more, at what cost? School leavers and freshly graduated students face obstacles in their new social environment. The University of Mauritius has innovated very recently by affording Practicum Courses. A mechanism is set up to encourage undergraduate placement in the public and private sector to complete their training. Training institutions and other institutions were the priority of the government which has pledged for education for all (EFA). As from 1970, the Mahatma Gandhi Institute (MGI) was established by an Act of Parliament after a joint venture with the government of India followed by the Mauritius Institute of Education, which was set up in 1973 by an Act of Parliament and replaced the existing Teachers' Training College (TTC).

Between 1970 and 1973, the Mauritius College of the Air was established with a strong link with the International Extension College (IEC) in Great Britain. However, the best achievement in vocational and technical institutions was the Industrial Vocational Training Board (IVTB) which is now restyled the Mauritius Institute of Training and Development (MITD) and the Hotel School of Mauritius (HSM), which is restyled as the Ecole Hôtelière Sir Gaëtan Duval, with a view to encourage the prompt management and leadership skills in emerging sectors (tourism, information and communication technology, the banking sector) in Mauritius. The MITD and the HSM are expanding to include undergraduate programmes and trainings which are offered to facilitate a transition from tertiary education to employment or selfemployment. Once more, training in some key sectors (tourism, banking sector) is insufficient. The first Industrial Trade Training Centre (ITTC) was launched in 1969 with support from the International Labour Organisation (ILO). Up to now, there are more and more registered professional bodies (Table 4) in Mauritius to enable degree holders to complete their training in hospitals, clinics or with a pupil master to broaden their knowledge and keeping them abreast of developments in their fields, encouraging them to share experiences with their professional skills.

\section{Table 4: List of registered professional bodies in Mauritius}

\begin{tabular}{ll}
\hline 1 Professional Architects Council & $\begin{array}{l}6 \text { Department of Civil Aviation } \\
\text { 2 Mauritius Institute of Professional Accountants } \\
7 \text { Council of Registered Professional Engineers of } \\
\text { Mauritius }\end{array}$ \\
$\begin{array}{l}\text { 8 Nursing Council of Mauritius } \\
\text { 4 Mauritius Veterinaries Association }\end{array}$ & 9 Chairman Dental Council of Mauritius \\
5 Institution of Occupational Safety \& Health & 10 Council of Legal Education (now restyled Council for \\
Management & Vocational Legal Education-CVLE). \\
\hline
\end{tabular}

This year 2011, the University of Mauritius has been selected as a study site for the Scholarly Communication in Africa Programme (SCA programme), along with 3 other African Universities, by the Centre for Educational Technology and the Research Office of the University of Cape Town. The SCAP aims at increasing African 
Universities' contribution to regional and global knowledge production in terms of research output, publications, communication and is primarily concerned with enhancing visibility for African Research. Several institutes (Swami Dayanand Institute of Management or SDIM and the InstitutSupérieur de Technologie) will soon become tertiary institutions and the Mauritius College of the Air will be transformed into an Open University of Mauritius (OUM). Amity University, University of Madras, Indira Gandhi National Open University have developed courses on-line with the MCA with a view to enhance socioeconomic development in Africa.

\section{Conclusion and Recommendations}

Prior to socio-economic development of a country people need education first and not money. No country would survive economically for long with a high rate of illiteracy and hopeless politicians. The African countries shall open their education to overseas institutions and we have a lot to learn from their experts and scholars provided a reasonable standard of education is maintained. Lack of funds probably explains why African students still have very little access to British or Australian universities unless they want to join local institutions. With franchising and encouraging overseas partner institutions to settle in their country African tertiary education will open a gate to those students who could not afford to travel and study abroad. To combat illiteracy worldwide it is therefore the duty of the government and its relevant ministries to control fees so that students have access to tertiary education irrespective it is a foreign or local institution and that they also employable easily.

- Lectures are delivered in a Western tradition especially to concede a form of reverse colonialism and which are not very well adapted to local students. It is advisable that students in tertiary education before they join foreign universities must have demonstrated good skills in both English and French language.

- Students are very overcrowded on their respective campuses and it is advisable that both local and foreign institutions are well prepared in advance to have campuses suitable to accommodate all students to achieve quality and space management.

- Foreign students have visa facilities before joining their respective institutions in Mauritius. They are very often over burdened with administrative hassle and various obstacles (indeed there are institutions which are running their courses and programmes without any proper accreditation by the local authorities) when they arrive in Mauritius.

- Foreign students usually claim exemptions and it is recommended that are proper exemption and equivalence committee both at national and international level so that any degree or award has their recognition in Mauritius.

- The policy of the Mauritian government is that there shall be a degree holder in each and every Mauritian family. However, despite that this policy is welcome among students there is despair when they look for a job and this explain why there is la fuite des cerveaux of the most brilliant Mauritians to other countries like Cananda, UK, New Zealand, Australia and even India.

- Most tertiary institutions in Mauritian and foreign institutions which are well settled are offering in Mauritius (University of Coventry, University of Wolverhampton, Middlesex University) the same degree and the same award but only the fees are different. True they have professors from foreign institutions to check for benchmarking and that the minimum standard of education is reached. However, they pay a flying visit to Mauritius and whether they have time to check for the required standard of tertiary education for which they are paid is rarely justified.

- Local tertiary institutions have pain to fill their seats. Local students are sure they could join foreign tertiary institutions in Mauritius and secure a seat because the entry requirements are still less stringent. Nonetheless, these foreign institutions must secure high standard teaching and lecturing.

\section{References}

Arshad-Ayaz, A. (2008). From producing citizens to producing managers: education in a globalised world. In RP Hopson, CC Yeakey\& FM Boakari (eds). Advances in education in diverse communities: research policy and praxis.

Bohm, L. (2002). Global student mobility 2025: Forecasts of the global demand for international higher education, Media Briefing, IDP Education Australia. 
Carnoy, M. (2005). Globalization, educational trends and the open society. Open society Institute Education Conference: Education an open society: a critical look at new perspectives and demands. USA: Stanford University, School of Education.

De Zilwa, D. (2005). Using entrepreneurial activities as a means of survival: investigating the processes used by Australian universities to diversify their revenue streams, Higher Education 50, 387-411.

Currie, J. \& Newson, J. (1998). Globalisation and the universities, London: Sage.

Huang, F. (2006). Transnational higher education in mainland china: a focus on foreign degree-conferring programs, Research Institute for Higher Education (RIHE) Hiroshima University. International Publication Series, 10, 21-33.

Ismael, R. (1997). The role of the private sector in Malaysian education, in Z. Marshallsay, ed., Educational Challenges in Malaysia: Advances and Prospects, Monash Asia Institute, Clayton

Joshee, R. (2008). Neoliberalism versus social justice: a view from Canada. In RK Hopson, CC Yeakey\& FM Boakari (eds). Advances in education in diverse communities: research policy and praxis.

Knight, J. (2002). Trade in higher education services: the implications of GATS, The Observatory on borderless higher education, online information available at http://www.obhe.ac.uk/accessed on My 232004

McBurnie, G. (2002). The business of international branch campuses: four Australian case studies. International Higher Education, 19, 4-5

Mok, K. H. (1999). Education and the market place in Hong Kong and mainland China. Higher Education, 37, 133-58

Nelson, B. (2005a). Higher Education Report 2004-05. DEST

OECD Multilingual Summaries Education at a Glance 2013. OECD Indicators

Sugimoto, K. (2006). Australia's transnational higher education in the Asia-Pacific region: its strategies and quality assurance. RIHE International Publication Series, 10, 1-19

World Bank. (1995a). Priorities and strategies for education, Washington D.C: The World Bank

Xie, R. (2001). The educational internationalization in shanghai in global vision, China's Education: Research \& Review 1, 211-212, Beijing: Education Science Press

Yang, R. (2006). Transnational higher education in Hong Kong: an analysis. RIHE International Publication Series, 10, 35-58

Ziguras, C. (2005). International trade in education services: governing the liberalization and regulations of private enterprise, in M. Apple, J. Kenway and M.Singh (eds.), Globalizing Public Education: Polices, Pedagogies and Politics, New York: Peter Lang, 93-112. 